Original Research

\title{
Diversity of Bacterial Communities in the Acid Mine Drainage Ecosystem of an Abandoned Polymetallic Mine in Poland
}

\author{
Tomasz Clapa ${ }^{1 *}$, Dorota Narożna ${ }^{1}$, Rafał Siuda ${ }^{2}$, Andrzej Borkowski², \\ Marek Selwet ${ }^{3}$, Cezary Mądrzak ${ }^{1}$ \\ ${ }^{1}$ Department of Biochemistry and Biotechnology, Poznan University of Life Sciences, Poznań, Poland \\ ${ }^{2}$ Faculty of Geology, University of Warsaw, Warsaw, Poland \\ ${ }^{3}$ Department of General and Environmental Microbiology, Poznan University of Life Sciences, Poznań, Poland
}

Received: 26 February 2018

Accepted: 28 May 2018

\begin{abstract}
An investigation of microbial communities able to form biofilms and inhabiting an extreme acid mine drainage (AMD) polymetallic mine with $\mathrm{pH}$ ranging from 1.0 to 1.5 was carried out. Presented results concern an abandoned polymetallic mine that has not been studied so far. Geochemical analyses of the sampled area reveals a high concentration of heavy metals - especially arsenic and iron derived from the decomposition of arsenopyrite. Cryo-SEM analyses of hydrated biofilm reveals its structure and composition, showing intact extracellular polysaccharides (EPS) with minerals submerged in an EPS matrix. Thus a direct connection between bacteria and biotransformation of surrounding minerals can be observed. Microbial community analyses were carried out by using the non-cultivated method based on DNA extraction, cloning, sequencing, and molecular phylogenetics. Bioinformatics analyses reveals the presence of bacteria belonging to three phylogenic groups: Proteobacteria, Acidobacteria, and Actinobacteria. The majority of them were characterized as iron-oxidizing bacteria. The information presented in this work is critical to understand which microorganisms are important to AMD production in the studied area and involved in iron and sulfur cycles.
\end{abstract}

Keywords: acid mine drainage, biofilm, polymetallic mine, weathering zone, Cryo-SEM.

\section{Introduction}

Microorganisms in the environment rarely live as single planktonic cells. Most often they form a static consortium of microorganisms floating in mucus.

*e-mail: tom.clapa@gmail.com
Nowadays, those consortiums are described as a biofilm or a biolayer [1-2]. Biofilm is a very complex and dynamic structure in which a single microbial cell cooperates and functions like a multicellular organism. Biofilms can be formed by bacteria, fungi, and algae, as well as protozoans. Those multi-culture and 3-D structures built by one or many groups of microorganisms have an ability to attach to a biological or non-biological surface as well as to each other 
[3-4]. The biofilm can be characterized by heterogeneity of its structure, genetic biodiversity, complexity of interactions, and the presence of extracellular substances. Microorganisms that live in close proximity as friendly neighbors are very well organized and can produce a layer of mucus, called extracellular matrix [5-6]. That matrix contains a large amount of different substances. The main components of such a matrix are polymers, called EPS (extracellular polymeric substances); furthermore, polysaccharides, proteins, nucleic acids, surface active agents, phospholipids, and water [7-8]. This hydro-gel structure protects microorganisms living inside from drying and protects the cells against any environmental factors - both physical and chemical. Additionally, the matrix seems to be a communication path between microorganisms. They generate chemical signals and transport them through channels inside the matrix, which also facilitate nutrient spreading [9-11]. Floated fluid inside those channels surrounds micro colonies, transports oxygen, and removes the products of cell metabolism. The biofilms can be formed in every environment where humidity is at the optimal level and there are enough nutrients [12-13].

The weathering zones of sulphide ores are sites where a chemical process causes the oxidation of heavy metal sulphides. That process is often strongly accelerated by the biochemical activity resulting in the formation of acid mine drainage (AMD). In this context, the microorganisms can play the main role in geochemical cycles of metals. Many geochemical and geomicrobiological studies are focused on AMD and sulphur cycle microorganisms like chemolithoautotrophic sulphur bacteria [14]. Many obligatory and facultative autotrophic microorganisms can oxidize not only sulphides and sulphur but also some metals, especially iron, thus enhancing the development of the weathering zone. The result of the microbial activity is the development of strongly acidic conditions in the weathering zone of sulphidic ore deposits, resulting in the formation of AMD [15-18].

The aim of this study was geomicrobiological characterization of the weathering zone in the closed mine in Radzimowice and an investigation of the biodiversity of the microbial community in the studied area based on molecular phylogenetics. Those communities are occurring as biofilms in close association with mineral phases formed as a product of the weathering of mainly arsenic minerals. Thus, a cryo-SEM analysis for EPS-mineral interactions was analyzed as well. The microbial communities from Radzimowice have not been studied so far.

\section{Material and Methods}

\section{Area Description and Sampling}

The environmental samples were collected from a closed mine in Radzimowice. The polymetallic
Radzimowice deposit is located in the SE part of the Kaczawa Mountains (southwestern Poland) [19]. The area is formed of metamorphosed mudrocks of the Lower Paleozoic age [19]. Some of the adits are completely or partially filled by water. At the sides of probes, collection temperature is low and stable (about $7^{\circ} \mathrm{C}$ ). The samples of biofilms were collected into sterile polyethylene containers and transported to the laboratory.

\section{Chemical Compounds of Acid Mine Drainage}

The concentrations of heavy metals were determined in water samples taken from the adit in Radzimowice. Samples of water $(100 \mathrm{~mL})$ were filtered through a $0.45 \mu \mathrm{m}$ filter, then the samples in polyethylene containers were fixed by the addition of $1 \mathrm{~mL}$ of concentrated $\mathrm{HNO}_{3}$. Determinations of metals were conducted by emission spectroscopy using an ICP-OES Optima 5300 DV (Perkin-Elmer) spectrometer. Measurements of the $\mathrm{pH}$ and Eh were performed in situ by electrochemical methods using appropriate electrodes (Elmetron, Poland).

\section{Microscopic Analysis; Scanning Electron Microscopy (SEM and Cryo-SEM)}

Samples were collected by cutting out pieces from investigated microbial mats $(0.5 \times 0.5 \mathrm{~cm}$, and about $0.3 \mathrm{~cm}$ thick). The sections were taken from the region of mats with associated mineral phases. Then the sections were studied by SEM and Cryo-SEM. The preparation protocol for SEM included washing with distilled water, lyophilization, and gold coating (with the exception of studies using EDX, where samples were introduced into the microscope formulations without coating).

The protocol for Cryo-SEM samples included freezing in liquid nitrogen and direct introduction to the sublimation chamber at low temperature. Then the samples were coated with platinum in an argon atmosphere and the samples were inserted directly into the microscope. We used a Sigma microscope (Carl Zeiss Microscopy GmbH, Jena, Germany) with the EDX detector (Bruker), and Cryo-SEM microscope Auriga (Carl Zeiss Microscopy GmbH, Jena, Germany).

\section{XRD Analysis}

The samples of minerals associated with microbial mats were separated and ground in an agate mortar. Then an analysis was conducted using x-ray powder diffraction in a diffractometer (Panalytical X' Pert PRO MPD). Depending on the samples, the diffraction measurements were made in a capillary (DSH) or in a classical Bragg-Brentano system. In order to analyze mineral phases closely associated with microbial mats, the samples of microbial slime streamers were previously lyophilized and ground in an agate mortar. 


\section{Genomic DNA Isolation}

The DNA was isolated from environmental samples using a modified method developed by Ausubel et al. (2003) [20]. One gram of the sample material was placed into a sterile Eppendorf tube and centrifuged at $14.000 \mathrm{rpm}$ at $4^{\circ} \mathrm{C}$ for $7 \mathrm{~min}$. The supernatant was discarded and the pellet was dissolved in $100 \mathrm{mM}$ Tris $/ \mathrm{HCl}(\mathrm{pH}$ 8.0) until $\mathrm{pH}$ of the probe reached 6.8-7.0. After that, $450 \mu \mathrm{l}$ of TE buffer containing $4 \mathrm{mg} / \mathrm{ml}$ lysozyme was incubated for $1 \mathrm{~h}$ at $37^{\circ} \mathrm{C}$ on a horizontal shaker at $100 \mathrm{rpm} / \mathrm{min}$. The lysate was supplemented with $50 \mu \mathrm{l}$ of $10 \%$ SDS and $10 \mu \mathrm{l}$ of $20 \mathrm{mg} / \mathrm{ml}$ proteinase $\mathrm{K}$ and incubated for $1 \mathrm{~h}$ at $37^{\circ} \mathrm{C}$. In order to remove polysaccharides, $100 \mu \mathrm{l}$ of $5 \mathrm{M}$ $\mathrm{NaCl}$ solution was added and vortexed. Subsequently, $80 \mu \mathrm{l}$ of $10 \% \mathrm{CTAB}$ and $0.7 \mathrm{M} \mathrm{NaCl}$ was added, and the sample was vortexed and incubated for $10 \mathrm{~min}$ at $65^{\circ} \mathrm{C}$. Samples were extracted two times with an equal volume of chloroform $(500 \mu \mathrm{l})$ and centrifuged at $14.500 \mathrm{rpm}$ for $5 \mathrm{~min}$ at $4^{\circ} \mathrm{C}$. The aqueous phases were transferred into fresh Eppendorf tubes and DNA was precipitated by adding 0.7 volume of isopropanol. After gentle mixing the samples were left for $20 \mathrm{~min}$ at $-20^{\circ} \mathrm{C}$. Precipitates were collected by centrifugation at $7.000 \mathrm{rpm}$ for $10 \mathrm{~min}$ at $4^{\circ} \mathrm{C}$. The pellets were washed with $70 \%$ ethanol, dried, and resuspended in $40 \mu \mathrm{l}$ of autoclaved double-distilled water. The quality of genomic DNA was analysed by agarose gel electrophoresis.

\section{Amplification and Cloning of 16S rDNA Sequences}

The nearly complete $16 \mathrm{~S}$ rDNA gene sequence was amplified by PCR with primers $16 \mathrm{~S}$ f $5^{\prime}-\mathrm{AGG}$ CAG CAG TGG GGA ATA TT - 3' and 16S r 5' - ACT TGA CGT CAT CCC CAC CT - 3' (GeneAmp ${ }^{\circledR}$ PCR System 9700 - Applied Biosystems). PCR reactions were carried in a final volume of $25 \mu \mathrm{l}$. The reaction mixture contained 10 pmoles of each primer, 0.1 mmole of each dNTP, 1.0 U of Taq DNA polymerase, $2.5 \mu \mathrm{l}$ of $10 \mathrm{x}$ reaction buffer (Novazym), and $100 \mathrm{ng}$ of template genomic DNA. After initial denaturation at $94^{\circ} \mathrm{C}$ for 2 min., 30 cycles of denaturation at $94^{\circ} \mathrm{C}$ for $30 \mathrm{sec}$, annealing at $52^{\circ} \mathrm{C}$ for $30 \mathrm{sec}$, polymerisation at $72^{\circ} \mathrm{C}$ for $1 \mathrm{~min}$. followed by final polymerisation at $72^{\circ} \mathrm{C}$ for $4 \mathrm{~min}$. were applied. The PCR products were analysed on $1 \%$ agarose gels and cloned into p-GEM $\mathrm{T}$ Easy vector using a cloning kit (Promega - pGEM-T Easy Vector Systems), following the manufacturer's protocol, and introduced into competent Escherichia coli cells, (supplied with the cloning kit). Transformants were selected by $\alpha$-complementation test and grown overnight on plates with LB medium containing ampicillin $(50 \mu \mathrm{g} / \mathrm{ml})$, IPTG $(200 \mathrm{mg} / \mathrm{ml})$, and X-Gal $(20 \mathrm{mg} / \mathrm{ml})$. A total $4 \mathrm{ul}$ of 170 white $40 \mathrm{ul}$ of colonies were collected and plasmid DNA was isolated. The recombinant plasmids containing $16 \mathrm{~S}$ rDNA gene fragments were amplified using vector primers: M13F(-47) 5' - CGC CAG GGT TTT CCC AGT CAC GAC - 3' and M13R 5' - TCA CAC AGG AAA CAG CTA TGA $\mathrm{C}-3$ '. The reaction mixture was prepared as described above.

\section{Analysis of $16 \mathrm{~S}$ rDNA Sequences}

The amplified 16S rDNA products were analysed by the RFLP (restriction fragment length polymorphism) method. Sequences were hydrolysed with $C f o \mathrm{I}$ endonuclease at $37^{\circ} \mathrm{C}$ for $1 \mathrm{~h}$. The digestion products were separated in $1.7 \%$ agarose gel electrophoresis for $90 \mathrm{~min}$ at $80 \mathrm{~V}$. Bands were visualized by staining with ethidium bromide and UV illumination. RFLP patterns were grouped visually into OTUs (operational taxonomic units), and representatives of each OTU were selected for insert sequencing and analysis [21-23]. Clones description was given as follows: UP_mRX, where $\mathrm{X}$ is the clone number. They were sequenced with a BigDye terminator v3.1 cycle sequencing kit on an ABI 3100 automated capillary DNA sequencer (Applied Biosystems, USA). Sequences from this study were deposited in GenBank. The accession numbers are listed in Table S1.

The sequences were analysed with the BLAST program in the NCBI Genbank database. For phylogenetic analyses, the sequences were aligned using ClustalW. The phylogenetic tree and evolutionary analyses were performed using MEGA 6 [24] and the phylogenetic trees were constructed. The evolutionary history was inferred using the NeighborJoining method. The optimal tree with the sum of branch length $=3.25579637$ is shown. The percentage of replicate trees in which the associated taxa clustered together in the bootstrap test (100 replicates) is shown next to the branches. The evolutionary distances were computed using the p-distance method [25] and are in the units of the number of amino acid differences per site. The analysis involved 70 amino acid sequences. All positions containing gaps and missing data were eliminated. There were a total of 31 positions in the final dataset.

\section{Results and Discussion}

An approach based on non-cultivate microorganism studies was used in this work. Isolation of genomic DNA, amplification of specific gene, and sequencing were applied in order to estimate which microorganisms are able to grow together as communities in environmental biofilm. Furthermore, complex analyses of geochemistry of sample area and structure of the sample using the Cryo-SEM method were carried out.

The presented microbial mat was derived from the environment, which can be classified as the AMD due to the extremely low $\mathrm{pH}(1-1.5)$, high redox potential (250-350 mV), and significant concentrations of heavy 
metals, which are presented in Table 1. Determined concentrations of heavy metals were in the range $0.019 \mathrm{mg} / \mathrm{L}$ to $166 \mathrm{mg} / \mathrm{L}$ for cadmium and iron, respectively. Investigated microbial structures were similar to microbial mats described in the literature as so-called slime streamers that can be built by the microorganisms of the iron-sulphur cycle and, therefore, capable to oxidizing the reduced sulphur and iron compounds [18-19]. The slime streamers may cover the large surface of adits in the Radzimowice Mine, but their occurrence is always limited to the acidic environment (Fig. 1).

Microscopic analyses using scanning electron microscopy together with a Cryo-SEM system are presented in Fig. 2. Studies using the Cryo-SEM technique did not require any procedures which, during dehydration and fixation of the sample, could falsify the image of surface structure by collapsing into filamentous structures [26]. The microbial cells embedded in extracellular polymeric substances can be seen on the presented figures. These substances, which are produced in large quantities, form a remarkable dynamic structure that builds the microbial mats. Thus, EPS are the environment for microorganisms [11]. Interestingly, the presence of described microbial structures was always associated with the presence of specific mineral phases. On the Cryo-SEM images (Fig. 2) the presence of mineral phases related to or even embedded within the substance produced by microorganisms of slime streamers from Radzimowice can be seen. Dohnalkova et al. [26], investigating the natural biofilms from a uranium bioremediation field, also points out that the Cryo-SEM method allows us to see intact EPS structures interacting with minerals. After comparing other electron microscopy techniques, only samples from frozen-hydrated biofilm show ultrastructural preservation. Results obtained by [27] also proved that the Cryo-SEM technique is able to indicate interactions between archaea and minerals, thus providing information about the role of archaea in AMD formation as well as sulphur and iron cycles.

\section{Mineralogical Studies}

Mineralogical studies revealed the existence of seven mineral phases associated with microbial colonies (Fig. 3).

Jarosite $\left(\mathrm{KFe}_{3}\left(\mathrm{SO}_{4}\right)_{2}(\mathrm{OH})_{6}\right.$ (Figs 1c, 3a-b) occurs as yellow earthy coating on the wall and as clay-like sediment on the bottom of the mine galleries. It is a typical mineral phase that is crystallized inside bacterial communities. Single crystals of jarosite are very small (circa 1-3 $\mu \mathrm{m}$ ) and have ab idiomorphous shape. They are suspended inside of EPS. Jarosite coexists with schwertmannite and gypsum.

Schwertmannite $\quad\left(\mathrm{Fe}_{8} \mathrm{O}_{8}(\mathrm{OH})_{8-2 \mathrm{x}}\left(\mathrm{SO}_{4}\right)_{\mathrm{x}} \cdot \mathrm{nH}_{2} \mathrm{O}\right)$, together with jarosite, is a very common mineral found inside microbial mats (Figs 1d, 3c-d). This mineral creates cryptocrystalline masses and soft stalactites (up to $70 \mathrm{~cm}$ of length) associated with microbial communities. It typically forms thin crystals about 2-3 $\mu \mathrm{m}$ long, which build spherolitic aggregates. The basic method of identification of schwertmannite remains PXRD, but the poor crystallinity of the mineral causes some difficulties. The peaks on $\mathrm{x}$-ray powder diffraction patterns of schwertmannite are often diffuse and of low intensity. On the basis of the PXRD method small admixtures of goethite $(\mathrm{FeOOH})$ were identified within the schwertmannite accumulations.

Scorodite $\left(\mathrm{FeAsO}_{4}-2 \mathrm{H}_{2} \mathrm{O}\right)$ was identified in a marginal part of the sulfide weathering zone, about $5 \mathrm{~m}$ from the largest accumulation of microbial mat (Fig. 1e). It occurs in highly variable modes of aggregates, including powdery masses (up to $10 \mathrm{~cm}$ ) and thin coatings on weathered arsenopyrite. Sometimes scorodite incrustates the stalactitic bacterial community and creates stalactites (up to $10 \mathrm{~cm}$ ). The colour of this mineral varies from light green to brown. PXRD analysis shows that scorodite has good crystalinity. Sometimes scorodite co-occurs with amorphous pitticite and small amounts of zýkaite and kaňkite.

Pitticite $\left(\mathrm{Fe} \times\left(\mathrm{AsO}_{4}\right)\right.$ y $\left.\left(\mathrm{SO}_{4}\right)_{2} \cdot \mathrm{n} \mathrm{H}_{2} \mathrm{O}\right)$, (Fig. 1f) is a general name for poorly defined $\mathrm{Fe}$ arsenate sulphate

Table 1. Chemical composition of acid mine drainage from Radzimowice Mine.

\begin{tabular}{|c|c|c|c|c|c|c|c|}
\hline \multicolumn{9}{|c|}{$\mathrm{mg} / \mathrm{L}$} \\
\hline $\mathrm{Li}$ & $\mathrm{B}$ & $\mathrm{Na}$ & $\mathrm{Mg}$ & $\mathrm{Al}$ & $\mathrm{Si}$ & $\mathrm{K}$ & $\mathrm{Ca}$ \\
\hline 0.10 & 0.01 & 7.71 & 20.23 & 18.85 & 15.32 & 2.22 & 42.90 \\
\hline $\mathrm{Ti}$ & $\mathrm{V}$ & $\mathrm{Cr}$ & $\mathrm{Mn}$ & $\mathrm{Fe}$ & $\mathrm{Co}$ & $\mathrm{Ni}$ & $\mathrm{Cu}$ \\
\hline $\mathrm{bdt}$ & 0.07 & $\mathrm{bdt}$ & 0.81 & 165.72 & 0.38 & 0.61 & 15.51 \\
\hline $\mathrm{Zn}$ & $\mathrm{As}$ & $\mathrm{Se}$ & $\mathrm{Sr}$ & $\mathrm{Mo}$ & $\mathrm{Cd}$ & $\mathrm{Sn}$ & $\mathrm{Sb}$ \\
\hline 1.02 & 24.02 & $\mathrm{bdt}$ & 0.08 & $\mathrm{bdt}$ & 0.02 & $\mathrm{bdt}$ & $\mathrm{bdt}$ \\
\hline $\mathrm{Ba}$ & $\mathrm{La}$ & $\mathrm{W}$ & $\mathrm{Pb}$ & $\mathrm{Bi}$ & $\mathrm{U}$ & $\mathrm{P}$ & $\mathrm{S}$ \\
\hline 0.01 & 0.50 & 0.01 & 0.04 & bdt & bdt & 8.60 & 243.26 \\
\hline
\end{tabular}



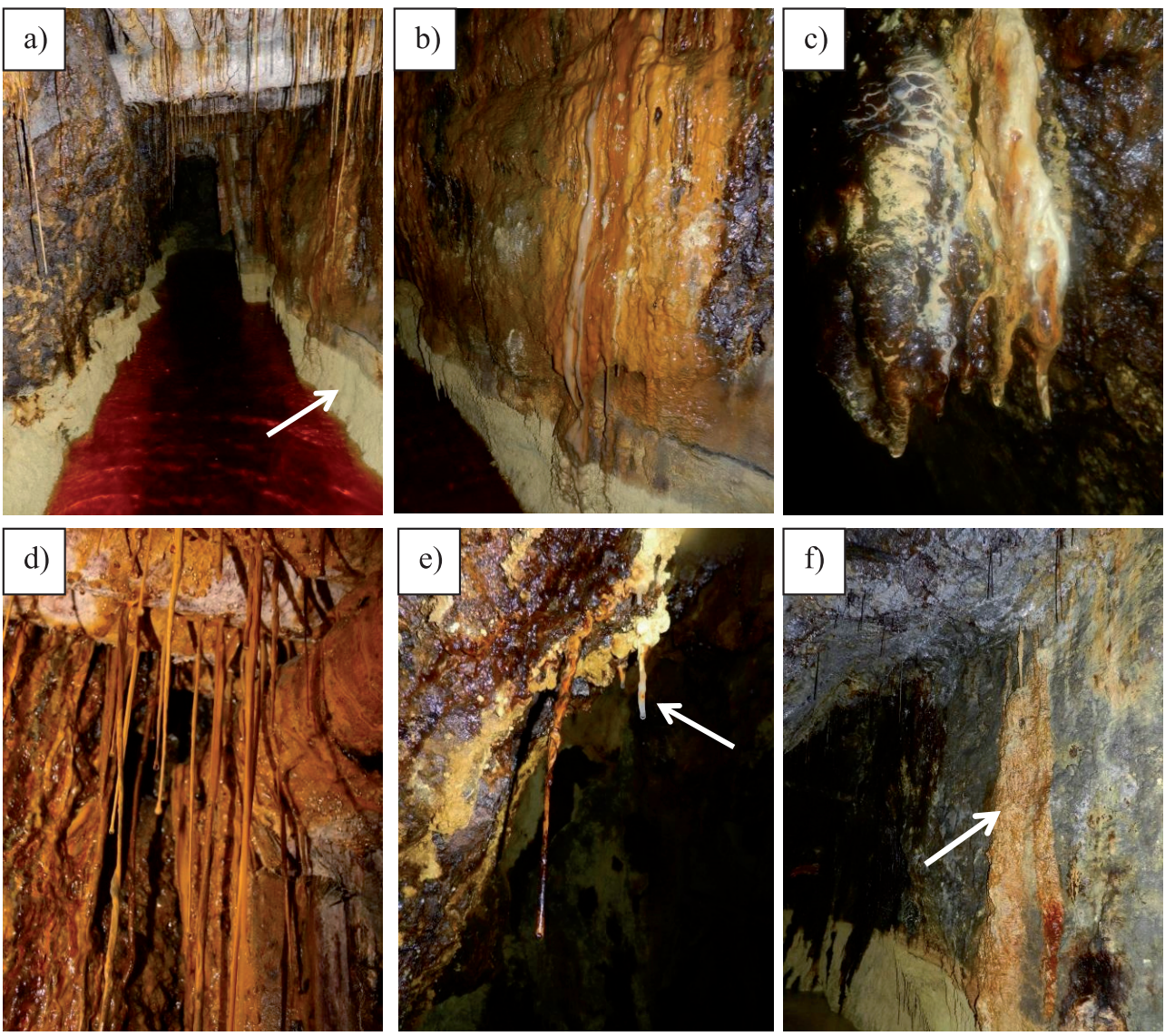

Fig. 1. Closed mine gallery with microbial slime streamers associated with mineral phases. a) Adit with AMD and microbial communities (Yellow jarosite is indicated). b) Microbial slime streamers on the wall of adit. c) Jarosite on the surface of microbial communities. d) Microbial communities mineralized by schwertmannite. e) Stalactite of scorodite (microbial communities associated with mineral phases are indicated). f) Dripstone of pitticite is indicated.
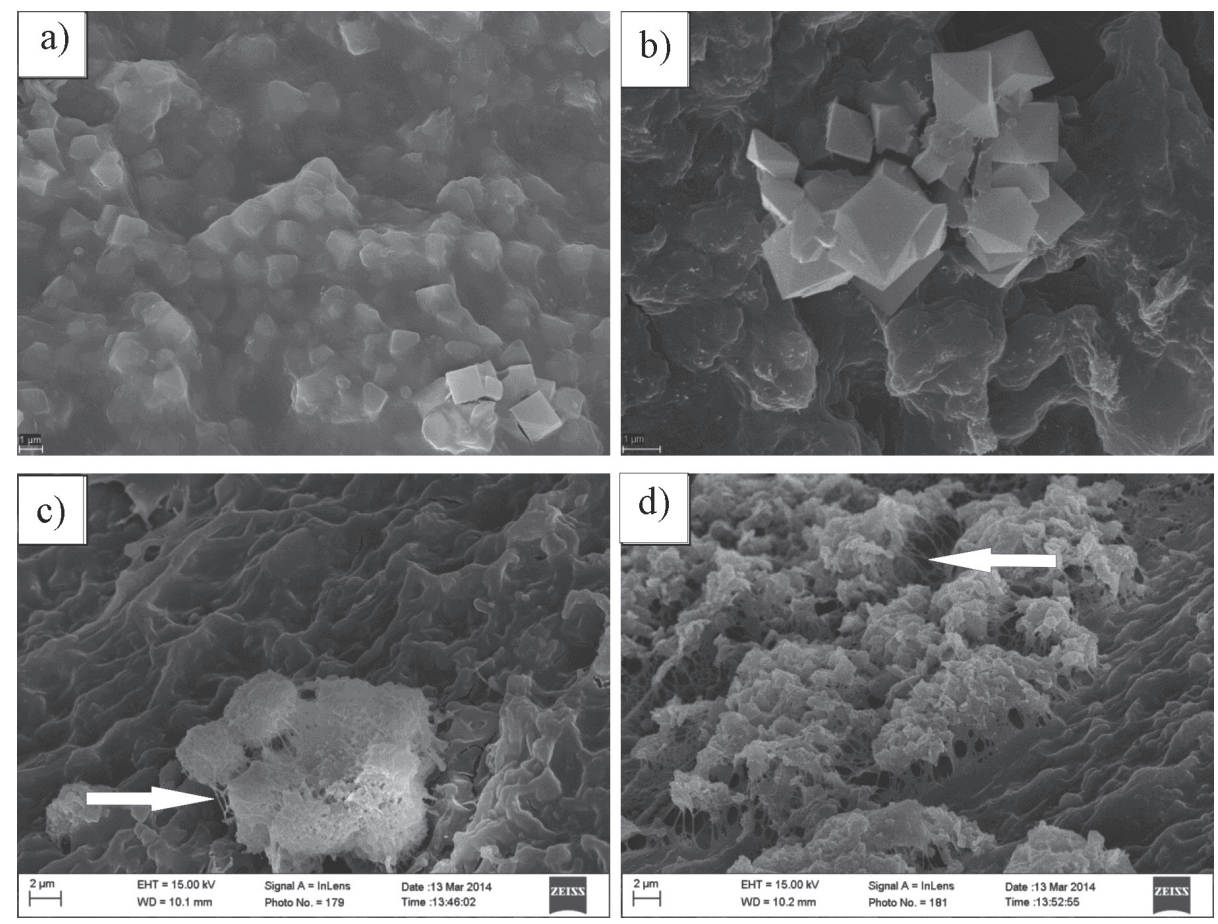

Fig. 2. Cryo-SEM analyses of microbial slime streamers from Radzimowice. a) Jarosite suspended in EPS. b) Jarosite on the surface of slime streamers. c), d) Surface of slime streamers with schwertmannite aggregates. Arrows indicates hydrated and intact structure of EPS and mineral phases. 
a)

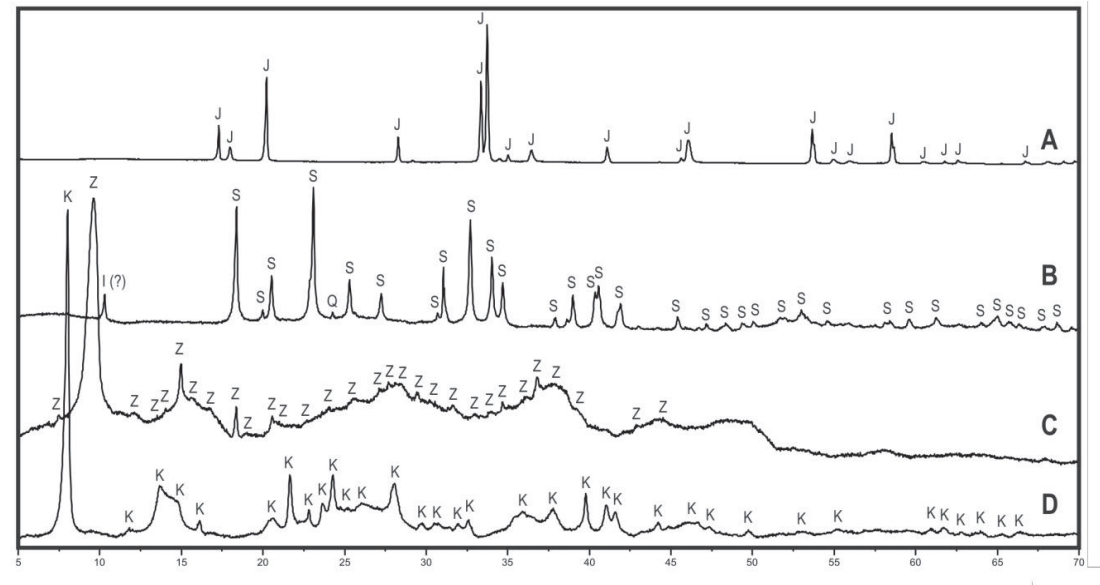

b)

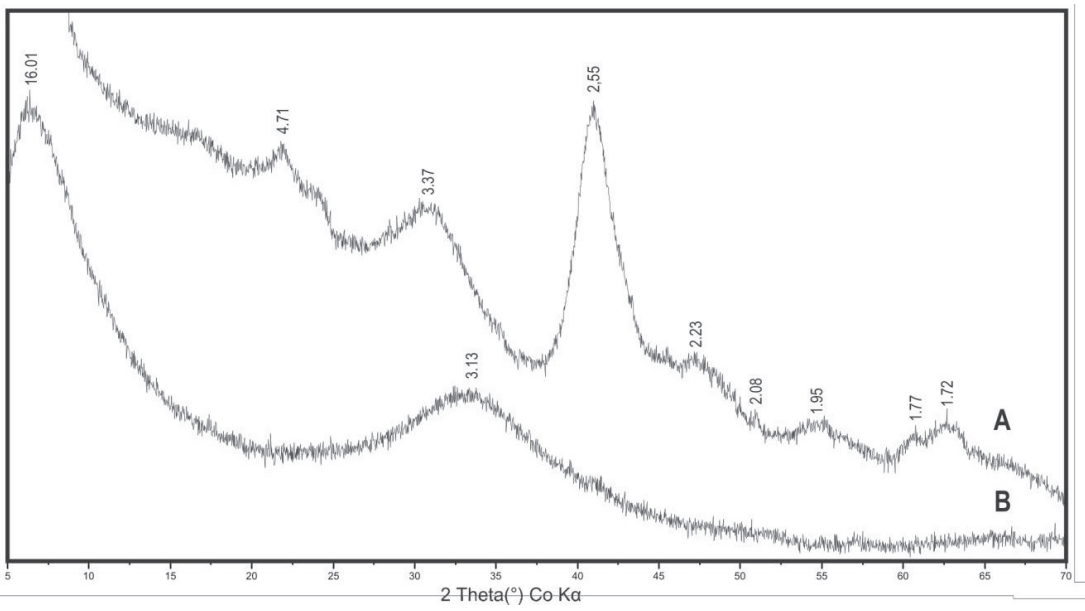

Fig. 3. a) X-ray diffraction patterns of the minerals connected with microbial communities A-jarosite (J), B-scorodite (S), C- zýkaite (Z), D- kaňkite (K); Q-quartz, I (?)-probably illite. b) X-ray diffraction patterns of the poorly crystalline mineral phases from microbial communities A-schwertmannite, B-pitticite.

hydrate mineral, which is amorphous to x-rays. Only three broad reflections with maximums at 1.60-1.62, 3.02-3.09, and 3.83-4.14 $\AA$ are present. Pitticite from the investigated zone builds small, dark-brown, or reddish-brown with waxy luster stalagmites up to $3 \mathrm{~cm}$ in length and stalactites up to $10 \mathrm{~cm}$. Accumulations of pitticite are associated with bacterial communities that occur in external parts of the described weathering zone.

Zýkaite $\left.\mathrm{Fe}_{4}\left(\mathrm{AsO}_{4}\right)_{3}\left(\mathrm{SO}_{4}\right)(\mathrm{OH}) \cdot 15 \mathrm{H}_{2} \mathrm{O}\right)$ is the most rarely observed mineral in the investigated weathering zone. It typically occurs as oval nodules up to $4 \mathrm{~cm}$ in size. Rarely, it forms isolated globules on the surface of rhyolitic rock. Zýkaite nodules are very soft, greasy, and plastic in ambient conditions. It has grey-white colour with a weak green shade and dull luster. Sometimes irregular aggregates of kaňkite grow on the zýkaite surface. The presence of zýkaite was confirmed using the PXRD method.

Kaňkite $\left(\mathrm{FeAsO}_{4} \cdot 3.5 \mathrm{H}_{2} \mathrm{O}\right)$ has been identified in several samples from the marginal part of the investigated "microbial zone." This mineral occurs as two types of aggregates. The first type of kan̆kite forms thin, pale green coats with botryoidal surface on the rhyolitic rocks containing weathered ore mineralization. Coats of kaňkite are composed of thin tabular crystals. The second variety occurs as yellow-green powdery

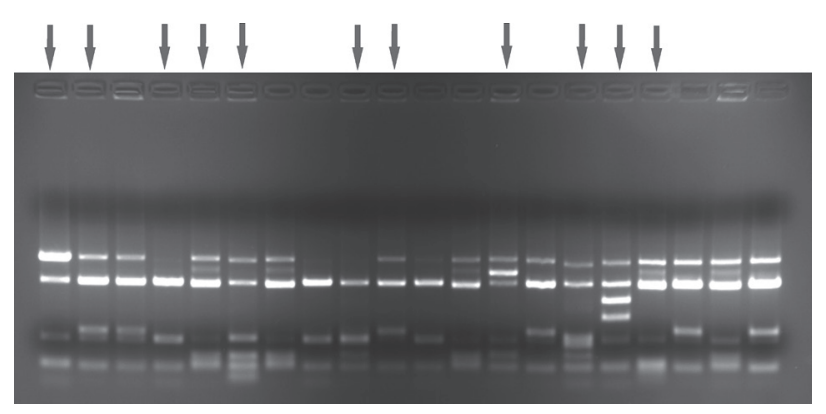

Fig. 4. Example of a gel after amplification of 16S rDNA gene and digestion with endonuclease $C f o$ I. Individual paths refer to different microorganism clones. Arrows indicate unique clone pattern. 
masses with dull luster. This type of kaňkite creates large aggregates with diameter up to $0.3 \mathrm{~m}$ and weighing up to $1 \mathrm{~kg}$. The biggest kaňkite specimens are found on the border between altered ore vein and wall rock, which was covered by communities of bacteria. The first type of kaňkite is present in paragenesis with small amounts of scorodite and zýkaite, while the second type is monomineral, without admixtures of other mineral phases.
Gypsum occurs rarely as small crystals (up to $0.5 \mathrm{~cm}$ ) growing on the walls of old mine galleries. It coexists with jarosite and pitticite.

\section{Molecular Studies}

After analyzing the total number of 200 clones by the RFLP method (Fig. 4), 31 clones were classified with different digestion patterns and thus were reamplified

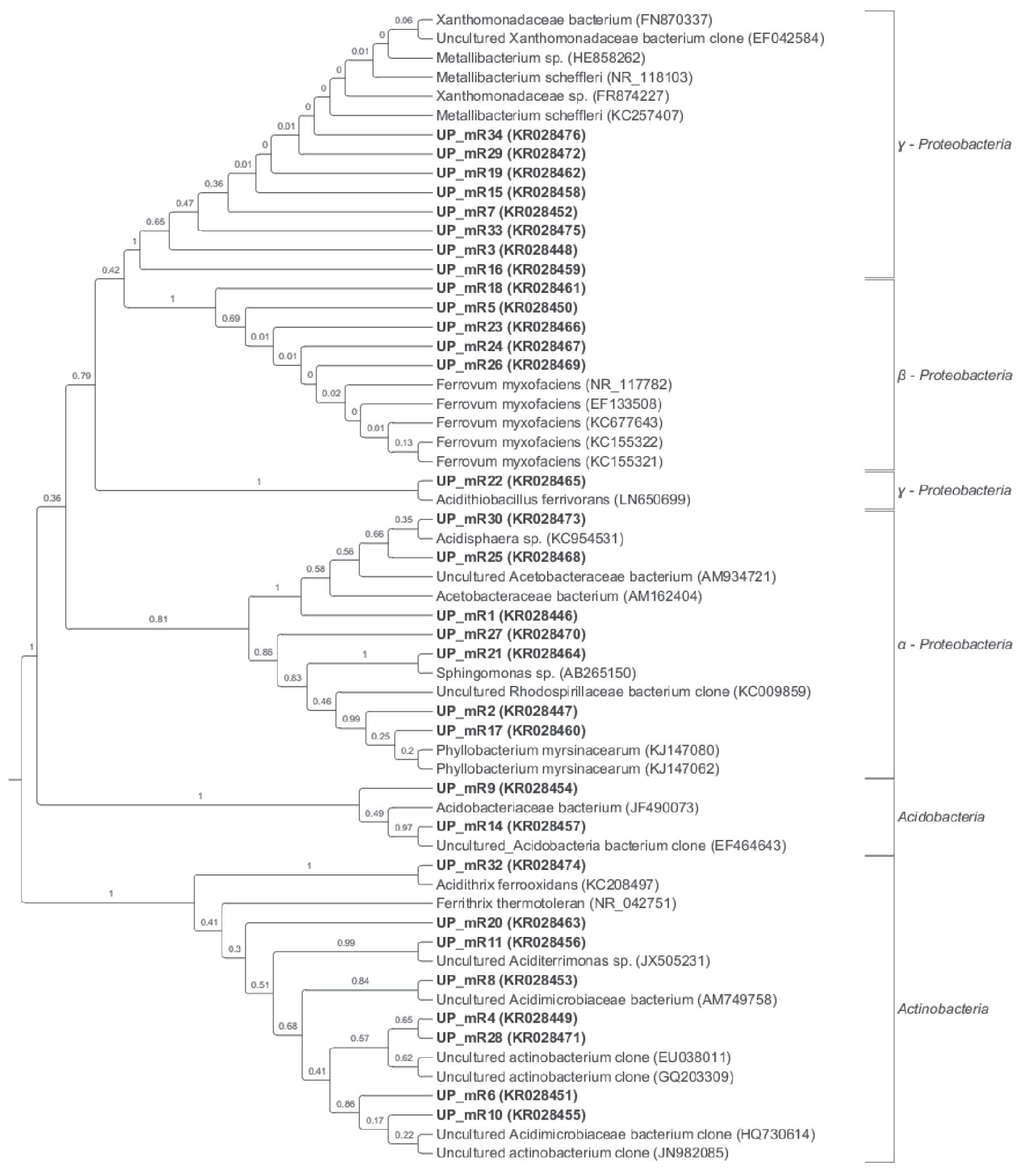

Fig. 5. A phylogenetic tree based on analyses of $16 \mathrm{~S}$ rDNA sequence. The clone numbers of uncultured microorganisms are indicated in uppercase boldface type (UP_mRX). 
and sequenced. Obtained sequences were related to the sequences of divisions that belonged to: Proteobacteria, Acidobacteria, and Actinobacteria (Table S1). The phylogenetic tree (Fig. 5) presents bacterial evolution distance and all obtained bacteria. Microorganisms that were able to adapt and live in the biofilm from Radzimowice in the majority were: Metallibacterium sp., Ferrovum myxofaciens, Metallibacterium scheffleri, Xanthomonas sp., Acidithiobacillus ferrivorans, Ferrithrix thermotolerans, and Acidithrix ferrooxidans, and were characterized as iron-oxidizing extremely acidophilic bacteria with acceleration of the oxidative dissolution of pyrite.

Comparable results were obtained by [28] during an investigation of iron-oxidizing acidophiles in acidic coal mine drainage. Results of his work are similar to ours and show that in the environments where $\mathrm{pH}$ is below 3.0 and the iron concentration is high, the microorganisms able to live there are mostly: Ferrovum sp. and Acidithiobacillus sp., Xanthomonadales, and Actinobacteria. Data shows that those groups of microorganisms are very common in such an environment, which was also described by [29], who had similar results characterizing the microbial community in a creek contaminated by acid mine drainage in China.

Kadnikov [30], during the investigation of the microbial community in AMD of a polysulfide ore deposit (eastern Siberia) with $\mathrm{pH}=2.6$, indicated that geochemical processes in that area are strictly connected with microbial biodiversity and that microorganisms are able to influence it. Furthermore, he indicated the same bacterial groups (phylum) as mentioned in our studies: Proteobacteria, Acidobacteria, Actinobacteria, Firmicutes, Nitrospirae, and more. Differences between microbiological compositions of those environmental samples could be connected with mineralogical composition of the sampled area. The $\mathrm{pH}$ in both cases was similar.

Interestingly, acidophilic Metallibacterium scheffleri was isolated also by [31] from pyrite acid mine biofilm samples and characterized as novel and alkalizing bacterium, able to reduce iron as well as oxidize it. Also [32] investigating AMD microbial communities from the two ponds in Turkey, with $\mathrm{pH} 2.8$ to 3.0. He shows acidophilic and iron-oxidizing bacteria, mostly from the Leptospirillum, Ferroplasma, and Acidithiobacillus groups, some of which correlates with results obtained by us, e.g., Acidithiobacillus ferrivorans. Similar results can be observed in work published by [33], who investigated metal-rich abandoned tailing ponds with very low $\mathrm{pH}(<2)$. He described the groups of bacteria, classifying them as Acidithiobacillus thiooxidans, Acidithiobacillus ferrooxidans, Leptospirillum ferrooxidans and more; however, these belong to the groups of sulfur and iron-oxidizing microorganisms.

It is necessary to conduct further analyses to characterize microorganisms of all members of bacterial communities able to grow in such extreme environments in order to better understand not only microbial communities able to grow there but also geochemical processes that are involved.

\section{Conclusions}

Analyses of environmental samples (especially biofilms) requires a combination of complex and sophisticated methods. Nowadays, new techniques can be applied into biological sciences.

Through conducting geochemical analyses and implementing the Cryo-SEM technique we were able to see what type of minerals can be produced and transformed by microorganisms as a result of weathering processes in the studied area. This suggests that those bacteria are involved in geochemical cycles of minerals and the influence of AMD formation. We also confirmed that, in some cases, those microorganisms are able to grow in the environment with low content of chemical compounds. Furthermore, electron microscopies (CryoSEM) revealed an intact EPS matrix where bacteria live and are protected by it. Last but not least, molecular biology techniques classified microorganisms living in the biofilm. We were able to point out specific groups of bacteria and by using molecular phylogenetics, classify them into specific class of bacteria. Those results confirm that microorganisms that cannot fully grow in such extreme environments as planktonic cells are able to co-exist together with other species and fully grow there. Our results can be potentially significant in the biotechnology and industrial sectors, where new bacteria or their genes can be used for handling polymetallic waste in acidic environments. 
Table S1. Sequence homologies of the $16 \mathrm{~S}$ rDNA clone sequences from this work to sequences of their closest relatives retrieved from databases.

\begin{tabular}{|c|c|c|c|}
\hline Clones & Closest relative with accession number & $\begin{array}{l}\text { Sequence homology } \\
(\%)\end{array}$ & Phylogenetic \\
\hline UP_mR1 (KR028446) & Acetobacteraceae bacterium (AM162404) & 94.8 & $\alpha$-Proteobacteria \\
\hline UP_mR2 (KR028447) & Phyllobacterium myrsinacearum (KJ147062) & 98 & $\alpha$-Proteobacteria \\
\hline UP_mR3 (KR028448) & Metallibacterium sp.(HE858262) & 95.6 & $\gamma$-Proteobacteria \\
\hline UP_mR4 (KR028449) & Uncultured Actinobacterium clone (EU038011) & 96.2 & Actinobacteria \\
\hline UP_mR5 (KR028450) & Ferrovum myxofaciens (EF133508) & 98.8 & $\beta$-Proteobacteria \\
\hline UP_mR6 (KR028451) & $\begin{array}{l}\text { Uncultured Acidimicrobiaceae bacterium clone } \\
\text { (HQ730614) }\end{array}$ & 97.9 & Actinobacteria \\
\hline UP_mR7 (KR028452) & Metallibacterium scheffleri (NR_118103) & 99.1 & $\gamma$-Proteobacteria \\
\hline UP_mR8 (KR028453) & Uncultured Acidimicrobiaceae bacterium (AM749758) & 96.7 & Actinobacteria \\
\hline UP_mR9 (KR028454) & Acidobacteriaceae bacterium (JF490073) & 96.3 & Acidobacteria \\
\hline UP_mR10 (KR028455) & Uncultured Actinobacterium clone (JN982085) & 97.3 & Actinobacteria \\
\hline UP_mR11 (KR028456) & Uncultured Aciditerrimonas sp. (JX505231) & 95.7 & Actinobacteria \\
\hline UP_mR14 (KR028457) & Uncultured Acidobacteria bacterium clone (EF464643) & 98.8 & Acidobacteria \\
\hline UP_mR15 (KR028458) & Xanthomonadaceae sp. (FR874227) & 98.1 & $\gamma$-Proteobacteria \\
\hline UP_mR16 (KR028459) & Xanthomonadaceae bacterium (FN870337) & 98.7 & $\gamma$-Proteobacteria \\
\hline UP_mR17 (KR028460) & Phyllobacterium myrsinacearum (KJ147080) & 99.9 & $\alpha$-Proteobacteria \\
\hline UP_mR18 (KR028461) & Ferrovum myxofaciens (NR_117782) & 98.7 & $\beta$-Proteobacteria \\
\hline UP_mR19 (KR028462) & Metallibacterium scheffleri (KC257407) & 98.3 & $\gamma$-Proteobacteria \\
\hline UP_mR20 (KR028463) & Ferrithrix thermotolerans (NR_042751) & 93.4 & Actinobacteria \\
\hline UP_mR21 (KR028464) & Sphingomonas sp. (AB265150) & 99.3 & $\alpha$-Proteobacteria \\
\hline UP_mR22 (KR028465) & Acidithiobacillus ferrivorans (LN650699) & 98.4 & $\gamma$-Proteobacteria \\
\hline UP_mR23 (KR028466) & Ferrovum myxofaciens (KC677643) & 98.1 & $\beta$-Proteobacteria \\
\hline UP_mR24 (KR028467) & Ferrovum myxofaciens (KC155322) & 98.4 & $\beta$-Proteobacteria \\
\hline UP_mR25 (KR028468) & Acidisphaera sp. (KC954531) & 98.1 & $\alpha$-Proteobacteria \\
\hline UP_mR26 (KR028469) & Ferrovum myxofaciens (KC155321) & 98.3 & $\beta$-Proteobacteria \\
\hline UP_mR27 (KR028470) & $\begin{array}{l}\text { Uncultured Rhodospirillaceae bacterium clone } \\
\text { (KC009859) }\end{array}$ & 88.6 & $\alpha$-Proteobacteria \\
\hline UP_mR28 (KR028471) & Uncultured Actinobacterium clone (GQ203309) & 96.6 & Actinobacteria \\
\hline UP_mR29 (KR028472) & $\begin{array}{l}\text { Uncultured Xanthomonadaceae bacterium clone } \\
\text { (EF042584) }\end{array}$ & 98.7 & $\gamma$-Proteobacteria \\
\hline UP_mR30 (KR028473) & Uncultured Acetobacteraceae bacterium (AM934721) & 96.6 & $\alpha$-Proteobacteria \\
\hline UP_mR32 (KR028474) & Acidithrix ferrooxidans (KC208497) & 99.3 & Actinobacteria \\
\hline UP_mR33 (KR028475) & Metallibacterium sp. (HE858262) & 98.3 & $\gamma$-Proteobacteria \\
\hline UP_mR34 (KR028476) & Xanthomonadaceae sp. (FR874227) & 98.5 & $\gamma$-Proteobacteria \\
\hline
\end{tabular}




\section{Acknowledgements}

Our research was partially supported by the European Union within the European Regional Development Fund, through an Innovative Economy Grant (POIG.02.02.00-00-025/09).

\section{Conflict of Interest}

The authors declare no conflict of interest.

\section{References}

1. KOŁWZAN B. Analiza zjawiska biofilmu-warunki jego powstawania i funkcjonowania. Ochr. Śr. 33 (4), 3, 2011.

2. ELIAS S., BANIN E. Multi-species biofilms: living with friendly neighbors. FEMS Microbiol. Rev. 36 (5), 990, 2012.

3. PAMP S.J., STERNBERG C., TOLKER-NIELSEN T. Insight into the microbial multicellular lifestyle via flowcell technology and confocal microscopy. Cytometry A 75A (2), 90, 2009.

4. RENIER S., HÉBRAUD M., DESVAUX M. Molecular biology of surface colonization by Listeria monocytogenes: an additional facet of an opportunistic Gram-positive foodborne pathogen: Molecular mechanisms of $\mathrm{L}$. monocytogenes biofilm formation. Environ. Microbiol. 13 (4), 835, 2011.

5. JIAO Y., CODY G.D., HARDING A.K., WILMES P., SCHRENK M., WHEELER K.E., BANFIELD J.F., THELEN M.P. Characterization of extracellular polymeric substances from acidophilic microbial biofilms. Appl. Environ. Microbiol. 76 (9), 2916, 2010.

6. DREWNIAK L., MARYAN N., LEWANDOWSKI W., KACZANOWSKI S., SKLODOWSKA A. The contribution of microbial mats to the arsenic geochemistry of an ancient gold mine. Environ. Pollut. 162, 190, 2012

7. RAJI A.I., MÖLLER C., LITTHAUER D., VAN HEERDEN E., PIATER L.A. Bacterial diversity of biofilm samples from deep mines in South Africa. Biokemistri 20 (2), 53, 2008.

8. BAKER B.J., TYSON G.W., GOOSHERST L., BANFIELD J.F. Insights into the diversity of eukaryotes in acid mine drainage biofilm communities. Appl. Environ. Microbiol. 75 (7), 2192, 2009.

9. HAMMER B.K., BASSLER B.L. Quorum sensing controls biofilm formation in Vibrio cholerae: Biofilms in V. cholerae. Mol. Microbiol. 50 (1), 101, 2003.

10. DREWNIAK L., MATLAKOWSKA R., REWERSKI B., SKLODOWSKA A. Arsenic release from gold mine rocks mediated by the activity of indigenous bacteria. Hydrometallurgy 104 (3-4), 437, 2010.

11. JIAO Y., D'HAESELEER P., DILL B.D., SHAH M., VERBERKMOES N.C., HETTICH R.L., BANFIELD J.F., THELEN M.P. Identification of biofilm matrix-associated proteins from an acid mine drainage microbial community. Appl. Environ. Microbiol. 77 (15), 5230, 2011.

12. WILMES P., REMIS J.P., HWANG M., AUER M., THELEN M.P., BANFIELD J.F. Natural acidophilic biofilm communities reflect distinct organismal and functional organization. ISME J. 3 (2), 266, 2009.
13. BOZORG A., SEN A., GATES I.D. A new approach to model the spatiotemporal development of biofilm phase in porous media: Modelling biofilm growth in porous medium. Environ. Microbiol. 13 (11), 3010, 2011.

14. BOND P.L., DRUSCHEL G.K., BANFIELD J.F. Comparison of acid mine drainage microbial communities in physically and geochemically distinct ecosystems. Appl. Environ. Microbiol. 66 (11), 4962, 2000.

15. JOHNSON D.B. Biodiversity and ecology of acidophilic microorganisms. FEMS Microbiol. Ecol. 27 (4), 307, 1998.

16. BAKER B.J., BANFIELD J.F. Microbial communities in acid mine drainage. FEMS Microbiol. Ecol. 44 (2), 139, 2003.

17. GONZALEZ-TORIL E., LLOBET-BROSSA E., CASAMAYOR E.O., AMANN R., AMILS R. Microbial ecology of an extreme acidic environment, the Tinto river. Appl. Environ. Microbiol. 69 (8), 4853, 2003.

18. BORKOWSKI A., PARAFINIUK J., WOLICKA D., KOWALCZYK P. Geomicrobiology of acid mine drainage in the weathering zone of pyrite-bearing schists in the Rudawy Janowickie Mountains (Poland). Geol. Q. 57 (4), 601, 2013.

19. SIUDA R., KRUSZEWSKI Ł. Recently forming secondary copper minerals as indicators of geochemical conditions in an abandoned mine in Radzimowice (SW Poland). Geol. Q. 57 (4), 583, 2013.

20. AUSUBEL F.M., BRENT R., KINGSTON R.E., MOORE D.D., SEIDMAN J.G., SMITH J.A., STRUHL K. Preparation and analysis of DNA. In Book Current protocols in molecular biology. Publisher: Greene Pub. Associates; J. Wiley, The United Kingdom, 177-221, 2003.

21. SCHLOSS P.D., HANDELSMAN J. Introducing SONS, a tool for operational taxonomic unit-based comparisons of microbial community memberships and structures. Appl. Environ. Microbiol. 72 (10), 6773, 2006.

22. RAMETTE A. Quantitative community fingerprinting methods for estimating the abundance of operational taxonomic units in natural microbial communities. Appl. Environ. Microbiol. 75 (8), 2495, 2009.

23. SCHLOSS P.D., WESTCOTT S.L. Assessing and improving methods used in operational taxonomic unitbased approaches for 16S rRNA gene sequence analysis. Appl. Environ. Microbiol. 77 (10), 3219, 2011.

24. TAMURA K., STECHER G., PETERSON D., FILIPSKI A., KUMAR S. MEGA6: Molecular evolutionary genetics analysis version 6.0. Mol. Biol. Evol. 30 (12), 2725, 2013.

25. SAITOU N., NEI M. The neighbor-joining method: a new method for reconstructing phylogenetic trees. Mol. Biol. Evol. 4 (4), 406, 1987.

26. DOHNALKOVA A.C., MARSHALL M.J., AREY B.W., WILLIAMS K.H., BUCK E.C., FREDRICKSON J.K. Imaging hydrated microbial extracellular polymers: comparative analysis by electron microscopy. Appl. Environ. Microbiol. 77 (4), 1254, 2011.

27. EDWARDS K.J., BOND P.L., GIHRING T.M., BANFIELD J.F. An archaeal iron- oxidizing extreme acidophile important in acid mine drainage. Science. 287 (5459), 1731, 2000.

28. JONES D.S., KOHL C., GRATTENBERGER C., LARSON L.N., BURGOS W.D., MACALADY J.L. Geochemical niches of iron-oxidizing acidophiles in acidic coal mine drainage. Appl. Environ. Microbiol. 81 (4), 1242, 2015.

29. SUN W., XIAO E., KRUMINS V., DONG Y., XIAO T., NING Z., CHEN H., XIAO Q. Characterization of the microbial community composition and the distribution of 
Fe-metabolizing bacteria in a creek contaminated by acid mine drainage. Appl. Microbiol. Biotechnol. 100, 8523, 2016.

30. KADNIKOV V.V., IVASENKO D.A., BELETSKY A.V., MARDANOV A.V., DANILOVA E.V., PIMENOV N.V., KARNACHUK O.V., RAVIN N.V. Effect of metal concentration on the microbial community in acid mine drainage of a polysulfide ore deposit. Microbiology. 85 (6), 745, 2016.

31. ZIEGLER S., WAIDNER B., ITOH T., SCHUMANN P., SPRING S., GESCHER J. Metallibacterium scheffleri gen. nov., sp. nov., an alkalinizing gammaproteobacterium isolated from an acidic biofilm. Int. J. Syst. Evol. Microbiol. 63 (4), 1499, 2013.

32. AYTAR P., KAY C.M., MUTLU M.B., ÇABUK A., JOHNSON D.B. Diversity of acidophilic prokaryotes at two acid mine drainage sites in Turkey. Environ. Sci. Pollut. Res. 22, 5995, 2015.

33. YANG Y., LI Y., SUN Q. Archaeal and bacterial communities in acid mine drainage from metal-rich abandoned tailing ponds, Tongling, China. Trans. Nonferrous Met. Soc. China 24, 3332, 2014. 
